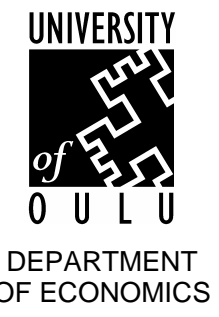

Working Papers

\title{
The Dynamic Effects of Country Specific Shocks in a Monetary Union
}

\author{
Seppo Orjasniemi \\ University of Oulu
}

Working Paper No. 0902

April 2009

ISSN 1796-7961 
Department of Economics

University of Oulu

Working Paper No. 0902

\title{
The Dynamic Effects of Country Specific Shocks in a Monetary Union*
}

\begin{abstract}
This paper uses a dynamic stochastic general equilibrium model with three countries to study the effects of implementation of an open monetary union on international fluctuations. We consider the effects of unanticipated country specific shocks on technology and government spending. We compare the resulting fluctuations to a benchmark case with three independent currencies. We find that the implementation of monetary union reverses the expenditure switching effects between the goods produced inside the monetary union and that the implementation of monetary union stabilizes the fluctuations caused by shocks emerging inside the monetary union. We also find that countries benefit more from positive technology shocks when they are members of a monetary union and that in the monetary union the negative spillovers resulting from fiscal expansion by one member country are rather small.
\end{abstract}

JEL Classification: F33, F41.

Keywords: Monetary union, government spending, terms of trade

Seppo Orjasniemi

Department of Economics

University of Oulu

P.O.Box 4600

FIN-90014 University of Oulu

FINLAND

e-mail: seppo.orjasniemi@oulu.fi

* I thank Mikko Puhakka, Juha Junttila and Lauri Vilmi and other members of the Oulu Macro Group for comments. I have also benefited from comments by seminar participants at the Bank of Finland and University of Oulu. I thank Tauno Tönning foundation for financial support. 


\section{Introduction}

Joining a monetary union (MU) changes the dynamics of a country's terms of trade. While the exchange rate fluctuations inside the monetary union are erased, the international trade with countries outside the MU is affected by the fluctuations of common currency. In this setup the country specific shocks emerging inside the monetary union are channeled to other member countries in two ways, through incomplete adjustment of bilateral terms of trade between the member countries and through fluctuations of the exchange rate of the common currency. The changes of these dynamics affect the international transmission of macroeconomic fluctuations. Indeed, a recent study by Gonçalves et al. (2009) shows that implementation of common currency has increased the bilateral correlation of business cycles in the euro area.

After the launching the third stage of European Monetary Union (EMU) in 1999 the research on monetary unions has proliferated. Authors including Devereux and Engel (2003), Kirsanova et al. (2004), Corsetti and Pesenti (2004), Beetsma and Jensen (2005) and Galí and Monacelli (2008) have studied the dynamics of monetary unions in various setups. These models, however, are restricted to the dynamics within the monetary union neglecting the trade with countries outside the monetary union. According to empirical results, international linkages outside the euro area are important to EMU members. Anderton and di Mauro (2007) argue that the euro area is more open to trade than United States and Japan. Lane and Milesi-Ferretti (2007) report that half of the international assets of the EMU countries are allocated outside euro area.

The number of studies considering the international linkages of monetary unions is increasing. Clausen and Wohltmann (2005) use a three country model to study international transmissions between countries of a monetary union and the rest of the world and monetary union. For example McAvinchey and McCausland (2007) study the impact of UK joining the euro with an empirical three country model. Campa and González-Mínguez (2006) study the pass-through of exchange rate changes into the prices of imports made by euro area countries originating outside the area. They find that most of these differences in transmission rates are caused by different degrees of openness of each country to non-euro area imports.

This paper studies the differences in international fluctuations caused by the introduction of a monetary union. We utilize a three country new open economy macroeconomics (NOEM) model to study the transmission of country specific macroeconomic shocks. This is done by comparing the dynamics of a system of three national currencies to dynamics of a system where two 
of the countries have formed a monetary union. By assuming producer currency pricing $(\mathrm{PCP})$ and nominal price rigidity, our model emphasizes the importance of exchange rate flexibility. In our model the monetary policy is the only stabilization tool, i.e. we ignore potential stabilizing channels like counter cyclical fiscal policy and automatic stabilizers.

We find that implementation of monetary union reverses the expenditure switching effects between the goods produced inside the monetary union and the introduction of $M U$ stabilizes the fluctuations of its economies. We also note that countries benefit more from the rise in productivity when they are members of a monetary union and the outcomes of fiscal policy are weaker when the country is member of a $M U$ and resulting no negative spillovers inside the monetary union.

The structure of the paper is as follows. Section 2 describes the model. Our model is based on the framework by Obstfeld and Rogoff (1995), so the basic details are presented briefly. In section 3 we discuss the transmission of macroeconomic shocks and their effects on expenditure switching. Section 4 concludes.

\section{The model}

To study the transmission of macroeconomic shocks in different exchange rate regimes this paper develops a model based on Obstfeld and Rogoff (1995). ${ }^{1}$ It consists of a dynamic stochastic general equilibrium model for three countries with staggered pricing as in Calvo (1983). We define a benchmark model with three independent currencies and modify it by introducing a monetary union between two of the countries. With both setups we study fluctuations caused by uncorrelated productivity and government consumption shocks.

\subsection{Prices and consumption}

The world consists of three countries of equal size. The countries are denoted by $H, U$ and $F$. Below the monetary union is formed by countries $H$ and $U$, therefore the countries $H$ and $U$ are referred to as $M U$ countries. Country $F$ is Foreign and country $H$ is Home. Each country is inhabited by a continuum of infinitely lived households, indexed on a unit interval.

All households are alike within each country. The production technology, consumption baskets and utility functions are identical in each country, thus

\footnotetext{
${ }^{1}$ The three country setup of this paper is also influenced by the work of Corsetti et al. (2000).
} 
below indexes denoting country specific variables are dropped where convenient. All households share the same preferences defined over a consumption index, real money balances and work effort. The aggregate variables are denoted by capital letters.

Households consume goods produced in each country in composite baskets. The elasticity of substitution between goods produced in the $M U$ and $F$ is denoted by $\mu$. The elasticity of substitution between goods produced in countries $H$ and $U$ is denoted by $\nu$. The CES consumption index $c_{t}$ is thus given by

$$
c_{t}=\left[\alpha_{1}^{\frac{1}{\mu}} c_{M U, t}^{\frac{\mu-1}{\mu}}+\left(1-\alpha_{1}\right)^{\frac{1}{\mu}} c_{F, t}^{\frac{\mu-1}{\mu}}\right]^{\frac{\mu}{\mu-1}},
$$

where $c_{M U, t}$ and $c_{F, t}$ are the consumptions of goods produced in the $M U$ countries and at the country $F$. The consumption index of goods produced in $M U$ is given by

$$
c_{M U, t}=\left[\alpha_{2}^{\frac{1}{\nu}} c_{H, t}^{\frac{\nu-1}{\nu}}+\left(1-\alpha_{2}\right)^{\frac{1}{\nu}} c_{U, t}^{\frac{\nu-1}{\nu}}\right]^{\frac{\nu}{\nu-1}},
$$

where $c_{H, t}$ and $c_{U, t}$ are the consumptions of goods produced at home and in the other $M U$ country. Parameters $\alpha_{1}$ and $\alpha_{2}$ determine the consumption shares when the prices are equal.

We denote prices in home currency without subscript and prices in other countries' currencies with subscripts $U$ and $F$. Given the above consumption basket, the consumption-based price index in country H's currency is given by

$$
P_{t}=\left[\alpha_{1} P_{M U, t}^{1-\mu}+\left(1-\alpha_{1}\right) P_{F, t}^{1-\mu}\right]^{\frac{1}{1-\mu}},
$$

and the consumption-based price index of goods produced in $M U$ countries is

$$
P_{M U, t}=\left[\alpha_{2} P_{H, t}^{1-\nu}+\left(1-\alpha_{2}\right) P_{U, t}^{1-\nu}\right]^{\frac{1}{1-\nu}} .
$$

With three currencies we have also three exchange rates. The nominal exchange rate between $H$ and $U$ is denoted by $S^{H U}$ and the nominal exchange rate between currencies of $H$ and $F$ is denoted by $S^{H F}$. With no arbitrage condition the exchange rate between currencies of $U$ and $F$ is defined by $S^{U F}=\left(S^{H U}\right)^{-1} S^{H F}$. The law of one price is assumed to hold. Since all consumers have identical consumption baskets, also the purchasing power parity holds, i.e. $P_{t}=S_{t}^{H U} P_{t}^{U}=S_{t}^{H F} P_{t}^{F}$. Nominal interest rate in country 
$H$ on period $t$ is given by

$$
1+i_{t}=\frac{E_{t}\left\{P_{t+1}\right\}}{P_{t}}\left(1+r_{t}\right)
$$

With analogous definitions for foreign nominal interest rate and real interest rate equality the uncovered interest parity holds, too.

In each country the goods are produced by a continuum of monopolistically competitive producers indexed on a unit interval. The firms produce differentiated goods which are consumed by local and foreign households in CES bundle

$$
c_{i, t}=\left[\int_{0}^{1} c_{i}(k)^{\frac{\psi-1}{\psi}} \mathrm{d} k\right]^{\frac{\psi}{\psi-1}}
$$

where $\psi$ denotes the elasticity of substitution between local goods. In the local currency, price index of goods produced in country $i$ is thus given by a CES aggregate

$$
P_{i, t}=\left(\int_{0}^{1} P_{i, t}(k)^{1-\psi} \mathrm{d} k\right)^{\frac{1}{1-\psi}}
$$

\subsection{Budget constraints and utility}

All households can borrow and lend on the integrated world asset markets. There is only one risk free real bond, denominated in units of the composite consumption. The real interest rate earned on bonds between periods $t$ and $t+1$ is denoted by $r_{t}$. The local currency and stock of bonds held by a local household at the end of period $t$ are denoted by $m_{t}$ and $f_{t}$ respectively. Households do not derive utility from foreign currencies. Household's labor supply is denoted by $\ell$ and the real wage earned from one unit of labor is denoted by $w$. The periodic real budget constraint of a representative household is given by

$$
f_{t}+\frac{m_{t}}{P_{t}}=\left(1+r_{t-1}\right) f_{t-1}+\frac{m_{t-1}}{P_{t}}+w_{t} \ell_{t}+\xi_{t}-c_{t}-\tau_{t}
$$

where $\tau_{t}$ denotes real value of taxes paid to the local government and $\xi_{t}$ denotes profits earned from local firms.

Household's utility depends positively on consumption and real balances and negatively on work effort. Using the local nominal prices and currency, the lifetime utility function of a typical household is

$$
U_{t}=E_{t}\left\{\sum_{s=t}^{\infty} \beta^{s-t}\left[\frac{c_{s}^{1-\sigma}}{1-\sigma}+\frac{\chi}{1-\epsilon}\left(\frac{m_{s}}{P_{s}}\right)^{1-\epsilon}-\frac{1}{1+\phi} \ell_{s}^{1+\phi}\right]\right\},
$$


where $\beta$ is the discount rate and we assume $0<\beta<1,0<\sigma, \epsilon \leq 1$ and $\phi, \chi>0$. In each period households choose $f_{t}, m_{t}$ and $l_{t}$ to maximize their utility subject to periodic budget constraint. The first-order conditions for this maximization problem are

$$
\begin{gathered}
E_{t}\left\{c_{t+1}^{\sigma}\right\}=\beta\left(1+r_{t}\right) c_{t}^{\sigma} \\
\frac{m_{t}}{P_{t}}=\left[\chi c_{t}^{\sigma} \frac{1+i_{t}}{i_{t}}\right]^{1 / \epsilon} \\
\ell_{t}^{\phi}=w_{t} c_{t}^{-\sigma} .
\end{gathered}
$$

Conditions (4)-(6) hold in every country. The equilibrium is fully characterized by the periodic budget constraint (2), the first-order conditions (4)-(6) and the transversality condition.

In each country the monetary policy is conducted by the national central bank, who are committed to a strategy of strict inflation response. The money supply rule in log-linear form is

$$
\hat{M}_{t}=-\left(\hat{P}_{t}-\hat{P}_{t-1}\right)
$$

where variables with hat denote the percentage deviation from initial steady state value. ${ }^{2}$ As central bank attempts to offset the distortions associated with staggered price setting, the target level of inflation is zero. ${ }^{3}$ In every country the seigniorage revenues are collected by the local government.

In each country government buys only locally produced goods in a CES bundle

$$
G_{i, t}=\left[\int_{0}^{1} g_{i}(k)^{\frac{\psi-1}{\psi}} \mathrm{d} k\right]^{\frac{\psi}{\psi-1}} .
$$

The public spending is financed by lump sum taxes and seigniorage revenues. The budget constraint of the government in country $i$ is

$$
G_{i, t}=\tau_{i, t}+\frac{M_{i, t}-M_{i, t-1}}{P_{t}^{i}}
$$

With the above specifications for private and public consumption and market clearing condition, the aggregate outputs of each country are given

\footnotetext{
${ }^{2}$ This money supply rule is a simplified version of the one described by Pierdzioch (2004).

${ }^{3}$ See also Galí (2002) and Ascari (2004) for discussion about steady state inflation levels.
} 
by

$$
\begin{aligned}
Y_{H, t} & =\alpha_{1} \alpha_{2}\left(\frac{P_{H, t}}{P_{M U, t}}\right)^{-\nu}\left(\frac{P_{M U, t}}{P_{t}}\right)^{-\mu} C_{t}^{W}+G_{H, t} \\
Y_{U, t} & =\alpha_{1}\left(1-\alpha_{2}\right)\left(\frac{P_{U, t}^{U}}{P_{M U, t}^{U}}\right)^{-\nu}\left(\frac{P_{M U, t}^{U}}{P_{t}^{U}}\right)^{-\mu} C_{t}^{W}+G_{U, t} \\
Y_{F, t} & =\left(1-\alpha_{1}\right)\left(\frac{P_{F, t}^{F}}{P_{t}^{F}}\right)^{-\mu} C_{t}^{W}+G_{F, t}
\end{aligned}
$$

where $C_{t}^{W}$ denotes the aggregate world consumption, given by

$$
C_{t}^{W}=C_{H, t}+C_{U, t}+C_{F, t}
$$

\subsection{Local firms and domestic price}

A representative firm $k$ in country $i$ produces goods with linear production technology

$$
Y_{i, t}(k)=A_{i, t} \ell_{i, t}(k),
$$

where $A_{i, t}$ is a stochastic level of technology which is common to all firms in the respective country. Since firms face constant returns to scale, domestic aggregate output and labor demand are given by

$$
Y_{i, t}=\int_{0}^{1} Y_{i, t}(k) \mathrm{d} k, \quad L_{i, t}=\int_{0}^{1} \ell_{i, t}(k) \mathrm{d} k=\frac{Y_{i, t}}{A_{i, t}} .
$$

The nominal value of goods produced in country $i$ is

$$
Y_{i, t} P_{i, t}=\int_{0}^{1}\left[\left(c_{i}(k)+g_{i}(k)\right] P_{i, t}(k) \mathrm{d} k\right.
$$

Each firm takes the aggregate price level of the locally produced goods $P_{i, t}$ as given. Using the composite consumption index (1), we may write the fraction of national product produced by a local firm $k$ as

$$
Y_{i, t}(k)=\left(\frac{P_{i, t}(k)}{P_{i, t}}\right)^{-\psi} Y_{i, t}
$$

where $P_{i, t}(k)$ is the price set by firm $k$.

Price setting of local producers follows the rule by Calvo (1983). In each period $t$ a fraction $0<1-\rho<1$ of firms are randomly and independently chosen and permitted to choose their prices, while the prices of other firms 
remain unchanged. The optimal price set in period $t$ is denoted by $P_{t}^{\circ}$. The aggregate price level of goods produced in country $i$ in period $t$ is given by

$$
P_{i, t}=\left(\rho P_{i, t-1}^{1-\psi}+(1-\rho)\left(P_{i, t}^{\circ}\right)^{1-\psi}\right)^{\frac{1}{1-\psi}} .
$$

When permitted, a firm chooses its price to maximize the present value of profits over the period when the chosen price is in effect. Thus the problem of a firm $k$ is to choose $P_{i, t}^{\circ}(k)$ to maximize

$$
E_{t}\left\{\sum_{j=0}^{\infty} \beta^{j} \rho^{j}\left[P_{i, t}^{\circ}(k)\left(\frac{P_{i, t}^{\circ}(k)}{P_{i, t+j}}\right)^{-\psi} Y_{i, t+j}-P_{i, t+j} w_{i, t+j} \ell_{i, t+j}(k)\right]\right\}
$$

subject to the production technology

$$
\left(\frac{P_{i, t}^{\circ}(k)}{P_{i, t+j}}\right)^{-\psi} Y_{i, t+j}=A_{i, t+j} \ell_{i, t+j}(k) .
$$

The optimal price for the monopolistic producer in period $t$ is given by

$$
P_{i, t}^{\circ}(k)=\frac{\psi}{\psi-1} \frac{E_{t}\left\{\sum_{j=0}^{\infty}(\beta \rho)^{j} Y_{i, t+j}(k) P_{i, t+j} \frac{w_{i, t+j}}{A_{i, t+j}}\right\}}{E_{t}\left\{\sum_{j=0}^{\infty}(\beta \rho)^{j} Y_{i, t+j}(k)\right\}},
$$

where $w_{t} / A_{t}$ is the real marginal cost of the firm $k$. Using log-linear approximations of equations (10) and (11) we can solve for the log-linear price index of locally produced goods

$$
\hat{P}_{i, t}=\frac{\beta}{1+\beta} E_{t}\left\{\hat{P}_{i, t+1}\right\}+\frac{1}{1+\beta} \hat{P}_{i, t-1}+\frac{(1-\rho)(1-\beta \rho)}{(1+\beta) \rho}\left(\hat{w}_{i, t}-\hat{A}_{i, t}\right) .
$$

Because of the linear technology, the real profits of firm $k$ in country $i$ are simply given by

$$
\operatorname{profits}_{i, t}(k)=\left(1-\frac{w_{i, t}}{A_{i, t}}\right) Y_{i, t}(k) .
$$

All households are equal shareholders in the local firms, and the real profits are distributed to local households in shares of equal size. The aggregate profits in country $i$ are given by

$$
P_{i, t} \xi_{i, t}=\int_{0}^{1} \operatorname{profits}_{i, t}(k) \mathrm{d} k=\int_{0}^{1} P_{i, t}(k) Y_{i, t}(k) \mathrm{d} k-P_{i, t} \frac{w_{i, t}}{A_{i, t}} \int_{0}^{1} Y_{i, t}(k) \mathrm{d} k
$$

Using equations (9) and (8) we may write the real profits paid to households in country $i$ as

$$
\xi_{i, t}=\left(1-\frac{w_{i, t}}{A_{i, t}}\right) Y_{i, t} .
$$




\subsection{Monetary union}

We now define the monetary union between countries $H$ and $U$ by fixing the exchange rate $S^{H U}$ to unity. The monetary policy of $M U$ is conducted by the common central bank based on the union wide aggregates, with a money supply rule analogous to the one proposed in equation (7). With common currency and identical consumption baskets in both of the $M U$ countries the consumer price indexes of both $M U$ countries are equal, thus the money supply rule of the common central bank is simply given by

$$
\hat{M}_{M U, t}=-\left(\hat{P}_{t}-\hat{P}_{t-1}\right) .
$$

The money supplied by the common central bank is distributed to the households of two member countries to meet their demands given by equation (5). The ratio of aggregate money demands of countries $H$ and $U$ is a function of the ratio of aggregate consumptions,

$$
\frac{M_{H, t}}{M_{U, t}}=\left(\frac{C_{H, t}}{C_{U, t}}\right)^{\sigma / \epsilon} .
$$

Because the demand for the common currency in the union is the sum of money demands $M_{H}$ and $M_{U}$, we may write the distribution of common currency as

$$
\begin{aligned}
& M_{H, t}=\left(1+\left(\frac{C_{U, t}}{C_{H, t}}\right)^{\sigma / \epsilon}\right)^{-1} M_{M U, t} \\
& M_{U, t}=\left(1+\left(\frac{C_{H, t}}{C_{U, t}}\right)^{\sigma / \epsilon}\right)^{-1} M_{M U, t} .
\end{aligned}
$$

These shares of money stock are also used for calculating the shares of seignorage revenues to the local governments.

\subsection{Steady state}

Next we solve for the symmetric steady state values, where asset holdings in each country are zero and the prices are equal. To ensure the symmetry of the countries we set the parameters defining the aggregate demands, $\alpha_{1}$ and $\alpha_{2}$, to have values $\frac{2}{3}$ and $\frac{1}{2}$, respectively. In each country government spending in steady state is defined to be a constant fraction $\kappa$ of aggregate output. These steady state values apply for both cases, one with three currencies and one with MU, described above. 
Denoting the steady state values by bars, we can write the aggregate steady state price level of locally produced goods as

$$
\bar{P}^{1-\psi}=\rho \bar{P}^{1-\psi}+(1-\rho)\left(\bar{P}^{\circ}\right)^{1-\psi},
$$

i.e. $\bar{P}=\bar{P}^{\circ}$. The steady state consumer price index in domestic currency is given by $\bar{P}=\bar{P}^{\circ}$. Also by defining the steady state exchange rates to be one, we have $\bar{P}^{H}=\bar{P}^{U}=\bar{P}^{F}$.

The optimal price chosen by the firm $k$ in steady state is given by

$$
\bar{P}^{\circ}(k)=\frac{\psi}{\psi-1} \frac{\frac{1}{1-\beta \rho} \bar{Y}(k) \bar{P}}{\frac{1}{1-\beta \rho} \bar{Y}(k)} \overline{\bar{A}} .
$$

Rearranging equation (12) we get the steady state markup which is the inverse of the real marginal cost. Thus the real wage in steady state is

$$
\bar{w}=\frac{\psi-1}{\psi} .
$$

Using the steady state wage and market clearing conditions, we may write the aggregate profits of firms in one country as

$$
\bar{\xi}=\frac{\bar{C}+\bar{G}}{\psi} .
$$

In steady state seignorage revenues are zero and taxes $\bar{\tau}$ equal the steady state government spending. Household's real budget constraint in steady state is thus given by

$$
\bar{c}=\bar{w} \bar{\ell}+\bar{\xi}-\bar{\tau} .
$$

As the steady state productivity $\bar{A}$ is defined to be one, we have $\bar{Y}=\bar{L}$ and $\bar{G}=\kappa \bar{L}$. Aggregating equation (15) and inserting equations (13) and (14) to it, we can solve for the steady state labor supply,

$$
\bar{L}=\left[1+\frac{\kappa-\psi \kappa}{\psi-1}\right]^{-1} \bar{C} .
$$

Substituting this to the steady state version of the first-order condition for labor supply (equation 6), we may solve for the steady state level of consumption as

$$
\bar{C}=\left(\frac{\psi-1}{\psi}\right)^{\frac{1}{\sigma+\phi}}\left[1+\frac{\kappa-\psi \kappa}{\psi-1}\right]^{\frac{\phi}{\sigma+\phi}} .
$$


The steady state demand for currency in each country is given by

$$
\bar{M}_{i}=\left[\frac{1-\beta}{\chi}\left(\frac{\psi}{\psi-1}\right)^{\frac{\sigma}{\sigma+\phi}}\left[1+\frac{\kappa-\psi \kappa}{\psi-1}\right]^{\frac{\sigma \phi}{\sigma+\phi}}\right]^{\frac{1}{\epsilon}} .
$$

In the case with monetary union, the steady state demand for common currency is twice the demand given above.

The model is log-linearized around the initial symmetric steady state, where variables with initial steady state value of zero are normalized by consumption. Also the level of technology is normalized to one.

\section{Numerical simulations}

In this section we compare the dynamics resulting from macroeconomic shocks under the two monetary regimes, one with three flexible exchange rates and one with $M U$. First we describe the parameter values used in our simulations. Then we discuss the dynamics caused by technology shocks under the two cases. After that we discuss the dynamics caused by shocks on government consumption. Finally, we summarize the discussion.

\subsection{Parameterization}

The time frequency of the model is interpreted to be one quarter. For the annual interest rate of four percent the discount factor $\beta$ has a parameter value of .99. The price adjustment parameter $\rho$ is set to .75 implying average price duration of one year. The chosen values for $\beta$ and $\rho$ are standard in quarterly business cycle models. The parameters for elasticities of substitution $\mu$ and $\nu$ are set to 2.5. As in Galí (2002) the steady state markup is set to be 10 percent by setting the value of elasticity of substitution between locally produced goods $(\psi)$ to be 11 . The parameter $\chi$ is set to one. Mankiw and Summers (1986) have estimated the consumption elasticity of money demand $1 / \epsilon$ to be close to one. Following Betts and Devereux (2000) we choose to use the parameter value $\epsilon=1$. As usual in the related literature the utility from consumption is logarithmic i.e. $\sigma=1$ and disutility from labor effort is quadratic, i.e. we set $\phi=1$. The steady state share of public spending in GDP $\kappa$ is 23 percent, which is the average in the euro area. The model is solved with a toolkit developed by Uhlig (1995). 
(a) Consumption at $\mathrm{H}$

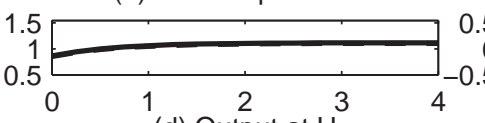

(d) Output at $\mathrm{H}^{3}$

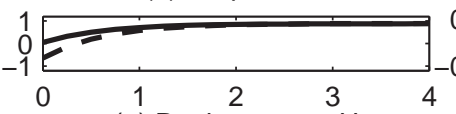

(g) Real wages at $\mathrm{H}$

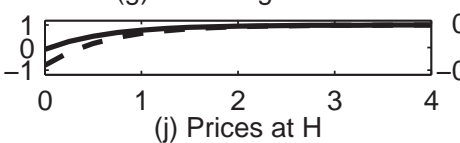

(j) Prices at $\mathrm{H}$

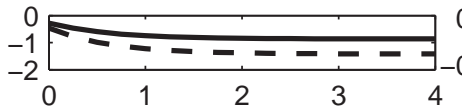

(m) Assets at $\mathrm{H}$

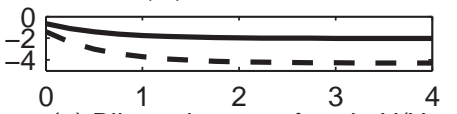

(p) Bilateral terms of trade $\mathrm{H} / \mathrm{U}$

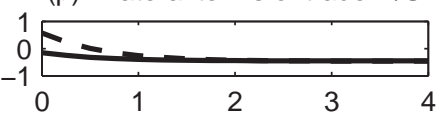

(s) Exchange rate $\mathrm{H} / \mathrm{U}$

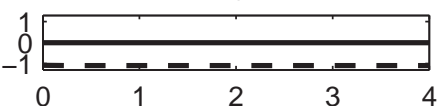

(b) Consumption at U

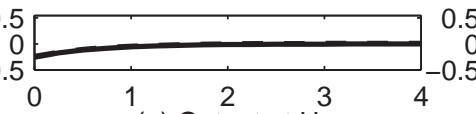

(e) Output at U

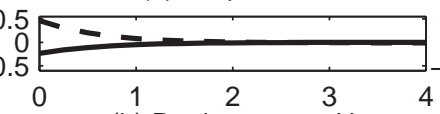

(h) Real wages at U

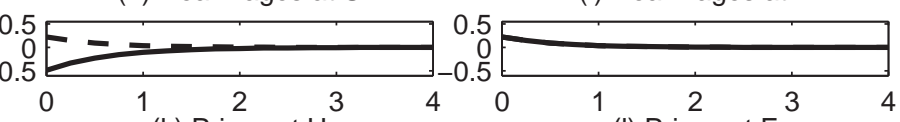

(k) Prices at $\mathrm{U}^{3}$

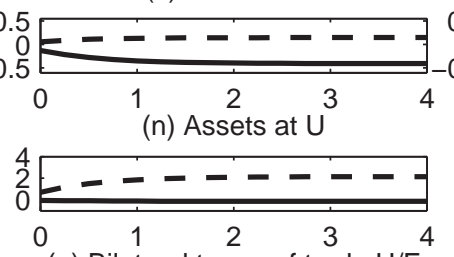

(q) Bilateral terms of trade U/F

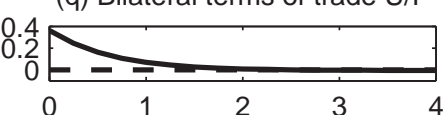

(t) Exchange rate U/F

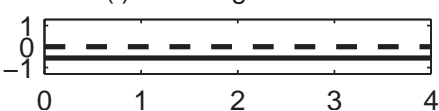

(c) Consumption at F

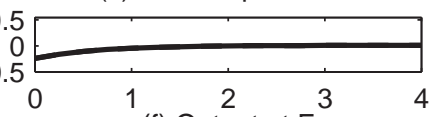

(f) Output at F

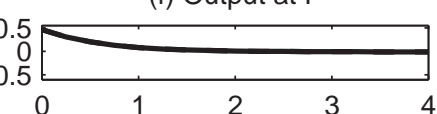

(i) Real wages at $\mathrm{F}$

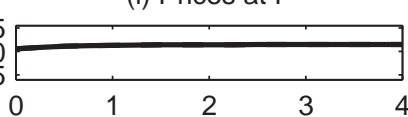

(o) Assets at F

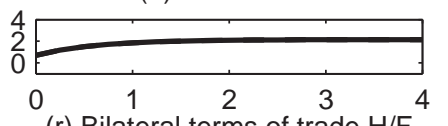

(r) Bilateral terms of trade $\mathrm{H} / \mathrm{F}$

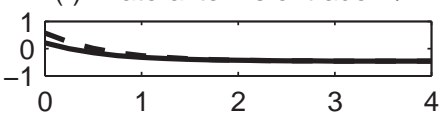

(u) Exchange rate $\mathrm{H} / \mathrm{F}$

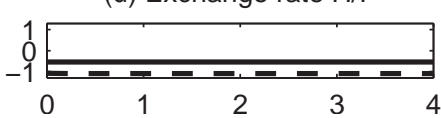

Figure 1: The effects of permanent one percent positive technology shock at country $H$. Solid lines represent the responses with $M U$ and dashed lines the responses without $M U$.

\subsection{Effects of a permanent technology shock}

We begin our analysis of the effects of monetary union on transmission of local macroeconomic shocks by studying the effects of permanent one percent unexpected positive technology shock in the Home country. The impulse responses for both cases, one with three independent currencies and one with $M U$, are presented in figure 1. In all figures below the vertical axes show the percentage deviations from initial steady state value. Changes in asset holdings are normalized by initial consumption level. The horizontal axes show the years after shock. The bilateral terms of trade are defined as the relative price of domestic goods in terms of domestic price of foreign goods.

Consider first the case with three independent currencies. The simulation results are in line with the previous literature. ${ }^{4}$ The positive technology shock

\footnotetext{
${ }^{4}$ Effects of technology shocks in NOEM framework are studied e.g. by Obstfeld and Rogoff (1995), Corsetti and Pesenti (2004), Tervala (2007) and Trabandt (2007).
} 
at $H$ leads to the appreciation of home currency against the other currencies. As shown in panels $\mathrm{s}$ and $\mathrm{t}$ of figure 1, the appreciation of the home currency is strong and reaches its new long-run level immediately. The appreciation of exchange rate increases the relative price of domestic goods, shifting both domestic and foreign demand away from goods produced in country $H$, as shown in panels $\mathrm{d}$ to $\mathrm{f}$ in figure 1 . Thus due to exchange rate appreciation the output in country $H$ falls and outputs in countries $U$ and $F$ rise in the short run. ${ }^{5}$ This result is in line with Galí (1999) and Tervala (2007). As shown in panels $\mathrm{j}$ to $\mathrm{l}$ in figure 1 , the prices of domestic goods start slowly to adjust downwards whereas the firms in countries $U$ and $F$ are able to raise their prices. The adjustment process continues until the level of real wages equals the marginal product of labor in each country. In the long run the permanent technology shock in country $H$ increases domestic consumption, real wages and output, and lowers the price of domestic goods. The new steady state prices of goods produced in countries $U$ and $F$ are higher than at initial steady state, but the long run changes in consumption and output are negligibly small. Due to expenditure switching in the short run, labor income of domestic households falls. To increase their consumption from the first period on, domestic households borrow from foreign households who in turn experience a short-run increase in their labor income.

Consider now the case with monetary union. The creation of monetary union removes the exchange rate fluctuations between the currencies of countries $H$ and $U$. In this case the positive technology shock in $H$ makes the common currency of countries $H$ and $U$ to appreciate against the currency of country $F$. Because of the symmetry of the countries this exchange rate appreciation is exactly half of the exchange rate appreciation of the preceding case, so the creation of monetary union doesn't affect the dynamics in country $F$. Now the appreciation of the common currency leads to an expenditure switching between goods produced in $M U$ and outside. This effect leads the producers in both countries of $M U$ to lower their prices and makes the producers in country $F$ to raise their prices. Since the technology shock has decreased the marginal costs in country $\mathrm{H}$, the domestic firms are able to cut down the prices faster than firms in country $U$. As shown in panel $\mathrm{m}$ of figure 1, the bilateral terms of trade between countries $H$ and $U$ does not appreciate in the short run as it did in the previous case. This means that the direction of short-run expenditure switching between the goods produced in countries $H$ and $U$ has changed. Indeed, when the monetary union is present

\footnotetext{
${ }^{5}$ With three independent currencies, the dynamics of variables in countries $U$ and $F$ are identical, so the nominal exchange rate between currencies of countries $U$ and $F$ stays unaltered and there is no expenditure switching between the products of these countries.
} 
the aggregate output in country $H$ doesn't fall in the short run as it did in the previous case. With higher demand the domestic producers are not forced to cut their prices as low as they had to in the former case. Compared to the previous case the ability of households in country $U$ to borrow is reduced. Thus with monetary union the new steady state asset level of households in country $H$ is higher than in the case with three independent currencies.

\subsection{Effects of a permanent rise in government spend- ing}

Next we consider the effects of one percent permanent rise on government expenditures in country $H$ on the world economy. The impulse responses to this shock are presented in figure 2. The simulation results are in line with previous literature. ${ }^{6}$

We begin our analysis again with the case of three independent currencies. As shown in figure 2 on panels $\mathrm{s}$ and $\mathrm{t}$, the rise of government spending at country $H$ leads to a strong immediate depreciation of home currency against the other currencies. Together with staggered pricing this depreciation of exchange rate induces a short-run fall on domestic terms of trade. Alongside with the increased public demand on domestic goods the expenditure switching from foreign goods to domestic goods increases the domestic output. As the domestic firms are now able to gradually adjust their prices upwards, the foreign firms have to reduce their prices to increase the demand they face. With increased labor income, the domestic households are able to accumulate assets by lending to foreign households who in turn experience a short-run fall in their income. In the long run the permanent one percent rise in government spending raises the domestic output and price of domestic goods and decreases the level of consumption by domestic households. In the foreign countries the new long run level of prices of local goods is lower than in the initial steady state, while the long-run changes in consumption and output are negligibly small.

Now we turn to the case of monetary union. In response to the rise of public spending in country $\mathrm{H}$, the exchange rate of common currency depreciates by exactly half of the value in the previous case. The depreciation of the exchange rate shifts consumption from goods produced in country $F$ to goods produced in the $M U$ countries. Because of the rise in government spending the producers in country $H$ are able to raise their prices more than producers in country $\mathrm{U}$, shifting more demand to goods produced in

\footnotetext{
${ }^{6}$ Effects of government spending shocks in NOEM framework are studied e.g. by Obstfeld and Rogoff (1995) and Ganelli and Lane (2002).
} 
(a) Consumption at $\mathrm{H}$

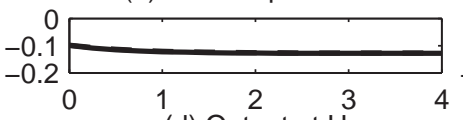

(d) Output at $\mathrm{H}$

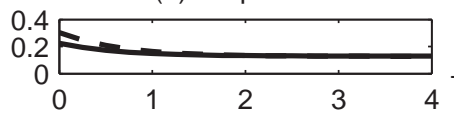

(g) Real wages at $\mathrm{H}$

(b) Consumption at U

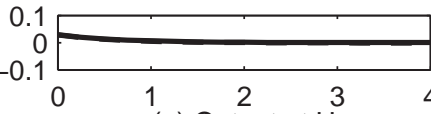

(e) Output at U

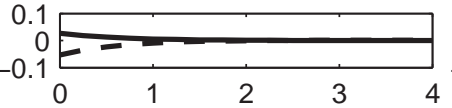

(h) Real wages at U
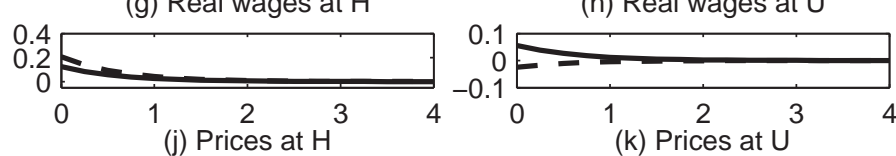

(k) Prices at U

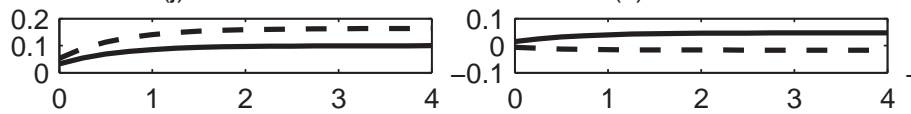

(m) Assets at $\mathrm{H}$

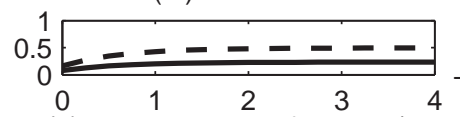

(p) Bilateral terms of trade $\mathrm{H} / \mathrm{U}$

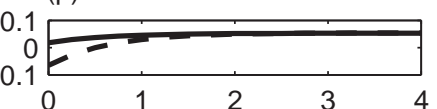

(s) Exchange rate $\stackrel{3}{H} / \mathrm{U}$
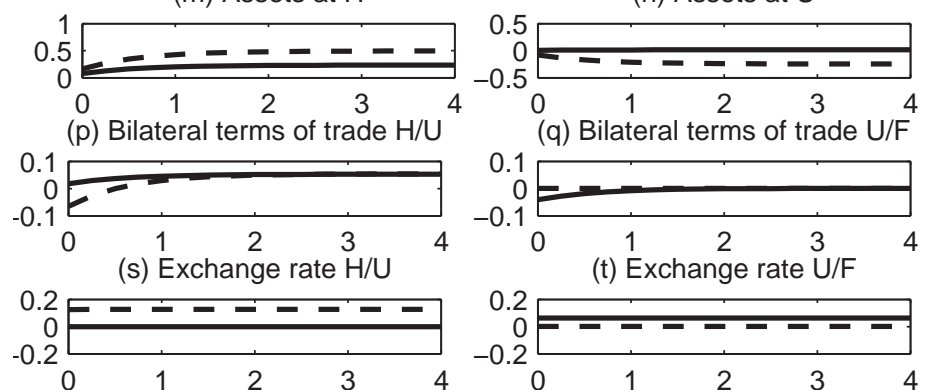

(q) Bilateral terms of trade U/F

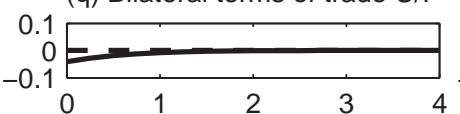

(t) Exchange rate U/F
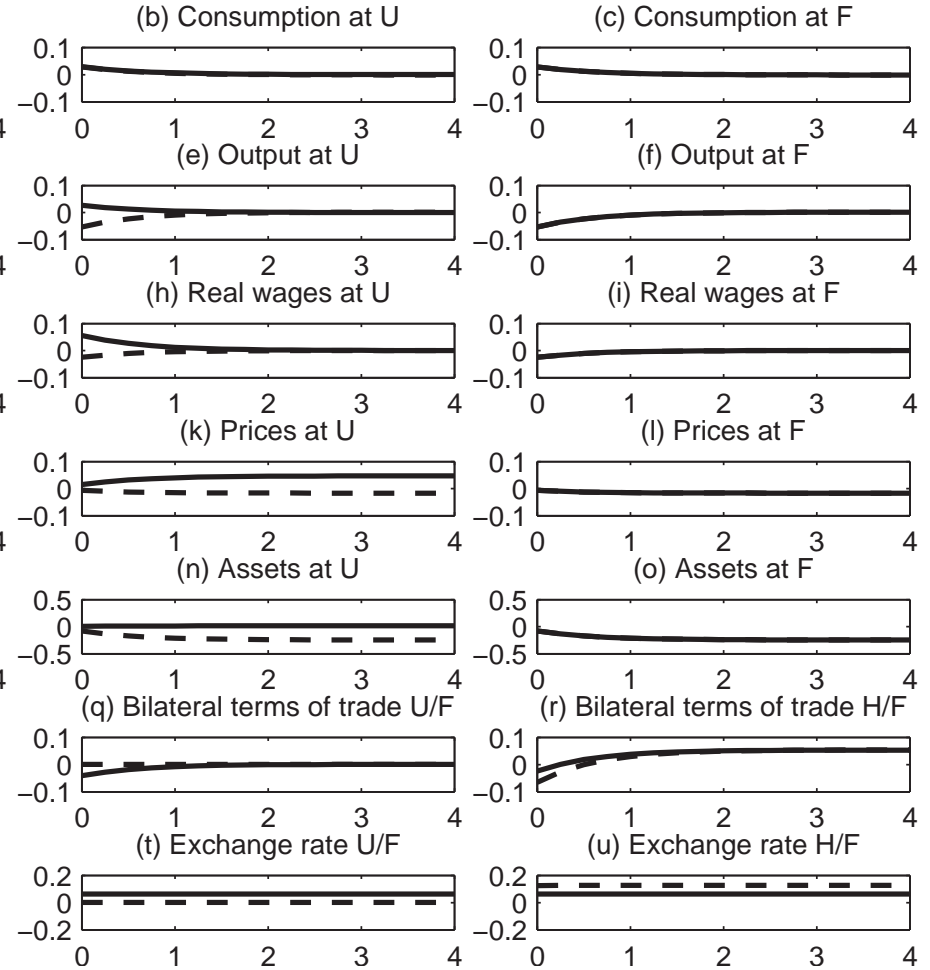

(f) Output at F

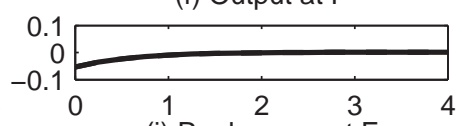

(i) Real wages at $\mathrm{F}$

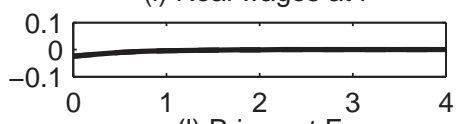

(I) Prices at F

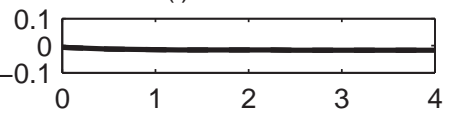

(o) Assets at F
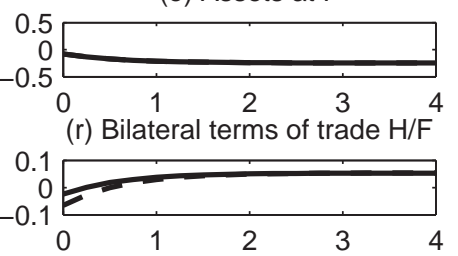

(u) Exchange rate $\mathrm{H} / \mathrm{F}$

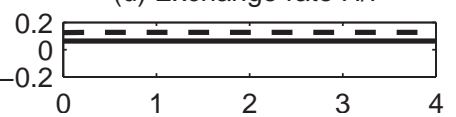

Figure 2: The effects of permanent one percent positive increase in government spendings at country $H$. Solid lines represent the responses with $M U$ and dashed lines the responses without $M U$.

country $U$. This means that the direction of the expenditure switching effect Compared to the previous case, the short-run raise of output in country $H$ is lower and there is no change in output of the country $U$ in the short run. Again in the long run, creation of monetary union has a considerable effect only on the price of goods produced in countries $H$ and $U$ and to the wealth accumulation in $M U$ countries. With three independent currencies the new steady state prices of goods produced in country $U$ were slightly lower than in initial steady state, while in the case with $M U$ they are higher, as shown in panel $\mathrm{k}$ of figure 2 . In turn the new steady state prices of goods produced in country $H$ are lower than in the previous case. The differences in price levels are balanced out by differences in wealth accumulations; lending from domestic households to the households of country $U$ is removed. 


\subsection{The effects of the monetary union}

In the simulations we have studied the effects of macroeconomic shocks arising from Home economy. We observe that the implementation of monetary union removes the exchange rate fluctuations between the $M U$ countries. The lack of exchange rate effects reverses the expenditure switching effects between the $M U$ countries compared to the setting with independent currencies. The exchange rate of the common currency reacts to shocks in parallel manner to the exchange rate of independent currency. These movements of exchange rate of the common currency lead to expenditure switching between the goods produced in both $M U$ countries and the goods produced outside of the $M U$.

In country $H$ the fluctuations of main macroeconomic variables resulting from both macroeconomic shocks considered above are weaker in the case with monetary union than in the case with three currencies, while the spillover effects to country $U$ are stronger with the $M U$. As noted earlier the positive technology shock does not cause a short-run fall in the aggregate output in the country in question. As the long-run levels of output are equal in both cases considered, we may conclude that countries benefit more from the rise in productivity when they are members of a monetary union. The outcomes of fiscal policy are weaker when the country is member of a $M U$. The negative spillover effects caused by expansive fiscal policy between two countries are reversed to positive when these countries form a monetary union. Thus sustainable increase in government spendings by other monetary union country is desirable.

In our analysis we have assumed full symmetry between the $M U$ countries. With this assumption the macroeconomic shocks emerging from the Foreign economy have symmetric effects on both countries. Thus in our setup the existence of the monetary union does not contribute to these shocks and they were left outside the analysis.

\section{Conclusions}

This paper studies the effect of monetary union on international fluctuations caused by country specific shocks. We develop a three-country NOEM model with staggered price setting and producer currency pricing to compare the dynamics of two setups, one with a monetary union by two countries and one with three independent currencies. We find that implementation of monetary union reverses the expenditure switching effects between the goods produced inside the monetary union. Also the fluctuations of common currency ex- 
tend the expenditure switching effects resulting from country specific shocks to affect the whole monetary union. We also study the effects of permanent shocks on technology and government spending. We find that countries benefit more from the rise in productivity when they are members of a monetary union and the outcomes of fiscal policy are weaker when the country is member of a $M U$ and resulting no negative spillovers inside the monetary union. We also note that the fluctuations resulting from a country specific shocks emerging inside the MU are weaker with monetary union than in the case with three currencies.

\section{References}

Anderton, R. and di Mauro, F. (2007). The external dimension of the euro area: stylished facts and initial findings. In Anderton, R. and di Mauro, F., editors, The external dimension of the euro area - assessing the linkages. Cambridge University Press.

Ascari, G. (2004). Staggered prices and trend inflation: Some nuisances. Review of Economic Dynamics, 7(3):642-667.

Beetsma, R. M. and Jensen, H. (2005). Monetary and fiscal policy interactions in a micro-founded model of a monetary union. Journal of International Economics, 67(2):320-352.

Betts, C. and Devereux, M. (2000). Exchange rate dynamics in a model of pricing-to-market. Journal of International Economics, 50(1):215-244.

Calvo, G. (1983). Staggered prices in a utility-maximizing framework. Journal of Monetary Economics, 12:383-398.

Campa, J. M. and González-Mínguez, J. M. (2006). Differences in exchange rate pass-through in the euro area. European Economic Review, 50(1):121 -145 .

Clausen, V. and Wohltmann, H.-W. (2005). Monetary and fiscal policy in a large asymmetric monetary union - a dynamic three-country analysis. Economics working papers 2005,18, Christian-Albrechts-University of Kiel, Department of Economics.

Corsetti, G. and Pesenti, P. (2004). Endogenous pass-through and optimal monetary policy: A model of self-validating exchange rate regimes. European University Institute. Manuscript. 
Corsetti, G., Pesenti, P., Roubini, N., and Tille, C. (2000). Competitive devaluations: toward a welfare-based approach. Journal of International Economics, 51(1):217 - 241.

Devereux, M. B. and Engel, C. (2003). Monetary policy in the open economy revisited: Price setting and exchange-rate flexibility. Review of Economic Studies, 70(4):765-783.

Galí, J. (1999). Technology, employment, and the business cycle: Do technology shocks explain aggregate fluctuations? American Economic Review, 89(1):249-271.

Galí, J. (2002). New perspectives on monetary policy, inflation, and the business cycle. NBER Working Papers 8767, National Bureau of Economic Research, Inc.

Galí, J. and Monacelli, T. (2008). Optimal monetary and fiscal policy in a currency union. Journal of International Economics, 76(1):116-132.

Ganelli, G. and Lane, P. R. (2002). Dynamic general equilibrium analysis: The open economy dimension. CEG Working Papers 20026, Trinity College Dublin, Department of Economics.

Gonçalves, C. E. S., Rodrigues, M., and Soares, T. (2009). Correlation of business cycles in the euro zone. Economics Letters, 102(1):56 - 58.

Kirsanova, T., Satchi, M., and Vines, D. (2004). Monetary union: Fiscal stabilization in the face of asymmetric shocks. CEPR Discussion Papers 4433, C.E.P.R. Discussion Papers.

Lane, P. R. and Milesi-Ferretti, G. M. (2007). The international equity holdings of euro area investors. In Anderton, R. and di Mauro, F., editors, The external dimension of the euro area - assessing the linkages. Cambridge University Press.

Mankiw, N. G. and Summers, L. H. (1986). Money demand and the effects of fiscal policies. Journal of Money, Credit and Banking, 18(4):415-29.

McAvinchey, I. and McCausland, W. (2007). The euro, income disparity and monetary union. Journal of Policy Modeling, 29(6):869 - 877.

Obstfeld, M. and Rogoff, K. (1995). Exchange rate dynamics redux. The Journal of Political Economy, 103(3):624-660. 
Pierdzioch, C. (2004). Capital mobility and the effectiveness of fiscal policy in open economies. Journal of Macroeconomics, 26(3):465 - 479.

Tervala, J. (2007). Technology shocks and employment in open economies. Economics: The Open-Access, Open-Assessment E-Journal, 1(2007-40).

Trabandt, M. (2007). Sticky information vs. sticky prices: A horse race in a dsge framework. Working Paper Series 209, Sveriges Riksbank (Central Bank of Sweden).

Uhlig, H. (1995). A toolkit for analyzing nonlinear dynamic stochastic models easily. Discussion Paper 97, Tilburg University, Center for Economic Research. 